\title{
Acclimating leaf celery plant (Apium graveolens) via bottom wet culture for increasing its adaptability to tropical riparian wetland ecosystem
}

\author{
BENYAMIN LAKITAN ${ }^{1,2, \boldsymbol{v}}$, KARTIKA KARTIKA ${ }^{1,3}$, SUSILAWATI $^{1}$, ANDI WIJAYA $^{1}$ \\ ${ }^{1}$ Faculty of Agriculture, Universitas Sriwijaya. Jl. Raya Palembang-Prabumulih Km 32, Indralaya, Ogan Ilir 30662, South Sumatra, Indonesia. \\ Tel.: +62-711-580169, Fax.: +62-711-580276, •email: blakitan60@unsri.ac.id \\ ${ }^{2}$ Research Center for Sub-optimal Lands, Universitas Sriwijaya. Jl. Padang Selasa No. 524, Bukit Besar, Palembang 30139, South Sumatra, Indonesia \\ ${ }^{3}$ Indonesian Institute of Science. Jl. Gatot Subroto, Jakarta Selatan 12710, Jakarta, Indonesia
}

Manuscript received: 23 September 2020. Revision accepted: 24 December 2020

\begin{abstract}
Lakitan B, Kartika, Susilawati, Wijaya A. 2021. Acclimating leaf celery plant (Apium graveolens) via bottom wet culture to increase its adaptability to the tropical riparian wetland ecosystem. Biodiversitas 22: 320-328. Bottom-wet culture was set up for acclimating leaf celery plant prior to cultivation at shallow water table conditions. The aim of this research was to evaluate adaptability of leaf celery plants to riparian wetland ecosystem. Leaf celery was selected as potential candidate since natural habitat of its wild relatives is marshlands. Shading at $0 \%, 20 \%$, and $60 \%$ was applied to reduced tropical sunlight intensity. Results of this study indicated that soil moisture was significantly increased in plants exposed to $60 \%$ shading, but leaf SPAD value was not significantly affected. Leaf celery is a perennial vegetable that can be frequently harvested. Weekly harvesting was rewarded with optimum yield and good quality leaves, i.e. high SPAD value (45.73 to 51.89). Delaying harvest to 3 weeks increased total yield but $52.12 \%$ of the harvested leaves were non-marketable. Mother plant of leaf celery produced suckers, but number of suckers only moderately correlated with yield $\left(\mathrm{R}^{2}=0.56\right)$. Plants exposed to $60 \%$ shading produced significantly less suckers $(9.00)$ than those exposed to full sunlight (12.46) and $20 \%$ shading (12.88) Use of zero intercept linear regression model, with length of leaf midrib (LLM) $\mathrm{x}$ leaf wingspan (LWS) as predictor, resulted in a geometrically based and accurate leaf area estimation model $\left(\mathrm{LA}=0.3431(\mathrm{LLM} \times \mathrm{LWS}) \mathrm{R}^{2}=0.87\right)$ for compound leaves of leaf celery plant. In conclusion, the most crucial factor in optimizing quantity and quality of yield was weekly harvesting focusing on marketable-size leaves.
\end{abstract}

Keywords: Asian cooking, delaying harvest, ethnic spice, leaf area estimation, perennial vegetable, shading treatment

Abbreviations: BWC: bottom wet culture; LA: leaf area; LLM: length of leaf midrib; LLP: length of leaf petiole; LSD: least squared difference; LTL: length of terminal leaflet; LWS: leaf wingspan; NPK: composite fertilizer consists of nitrogen, phosphor, and potassium; SPAD: Soil and Plant Analyzer Development; WAP: weeks after planting; WBW: weeks after bottom wet culture applied; WTL: width of terminal leaflet

\section{INTRODUCTION}

Leaf celery (Apium graveolens var. secalinum) is different from stalk celery (var. dulce) and aromatic tuber celery (var. rapaceum). Leaf celery is mostly cultivated for its leaves, used as fresh spice in Asian cooking. Natural habitat of celery and its wild relative is marshland (Herden et al. 2020); therefore, it is expected that this vegetable can be introduced to tropical wetland in Indonesia.

Tropical wetlands are characterized by high soil water content with shallow water tables and may also be temporarily waterlogged or flooded during rainy season. Most vegetable crops are susceptible to excessive water conditions, except for few native vegetables such as water spinach (Ipomoea aquatica) (Kaur et al. 2016) and yellow velvetleaf (Limnocharis flava) (Lakitan et al. 2018a; 2019). Excessive water condition limits diversity of crop cultivated at wetland ecosystem.

Leaf celery has not ever been intensively evaluated on its adaptability to tropical wetland ecosystem. Early assessment can be done by exposing roots of this vegetable to partially anaerobic rhizosphere, i.e. shallow water table conditions. In this case, soil pores at lower part of the rhizosphere are fully water-saturated (anaerobic condition), but upper part is wet but still allowing oxygen diffusion through soil pores (aerobic condition). Shallow water table commonly occurred at transitional zone between flooded and unflooded wetlands. In a flat landscape like in riparian wetlands, this shallow water condition can cover significant acreages. Many terrestrial vegetable crops have shown their adaptability to this transitional zone (Siaga et al. 2019; Susilawati and Lakitan 2019; Lakitan et al. 2018b; Meihana et al. 2017). Leaf celery could be another candidate for enriching diversity of vegetables cultivated at tropical riparian wetlands.

Partially anaerobic rhizosphere limits space for roots to explore, in search of nutrients and water. For offsetting limited water uptake by roots due to limited aerobic rhizosphere, transpiration can be restrained by lowering light energy absorbed on leaf surface. For this purpose, shading the plants with black polyethylene net has been commonly practiced (Abdel-Ghany et al. 2020).

In this study, leaf celery was directly exposed to sunlight or covered with black polyethylene net to achieve 
$0 \%, 20 \%$, and $60 \%$ light reduction during the first seven weeks after celery seedlings were transplanted into $30-\mathrm{cm}$ diameter pots. Afterward, all previously shade-treated plants were exposed to full sunlight. Five consecutive harvests were conducted during the full sunlight period. Carryover effect, delayed harvest effect on marketable yield, optimum harvest frequency, sucker contribution to yield, and leaf area estimation models were examined during adaptation stage for diversifying crops in tropical riparian wetland ecosystem. Delaying harvest is done for adjusting time of harvest to market demand.

\section{MATERIALS AND METHODS}

\section{Procedures}

\section{Experiment setup}

Commercial seeds of leaf celery (Apium graveolens var. secalinum) were soaked in water for six hours prior to being sown on soil-manure mix $(50 / 50 \mathrm{v} / \mathrm{v})$ in each cell of seedling trays. At 7 weeks after planting (WAP), seedlings with two cotyledon leaves and one true leaf were transferred to $10-\mathrm{cm}$ diameter black polyethylene bags filled with similar mix. After developing 3 to 5 true leaves, at 9 WAP, all seedlings were transferred to larger bags, i.e. 20-cm diameter, and fertilized with $2.5 \mathrm{~g}$ NPK per bag. Then, after seedlings had developed true leaves with multiple leaflets, at 11 WAP, they were transplanted in 30$\mathrm{cm}$ diameter pots filled with similar growing substrate, and then they were upheld in the pots. Bottom wet culture (BWC) system was commenced on the day of last transplanting was accomplished. After all, seedlings were transplanted into pots, the pots were placed into an outdoor experimental pool, marking the start of BWC system. The pool was filled with water to a $5 \mathrm{~cm}$ depth and maintained at this depth throughout growing season. A valve positioned at $5 \mathrm{~cm}$ above base of the pool was kept open for rainwater outlet. Prepared seedlings were more than twice of total seedlings required for this experiment; therefore, only vigorous and uniform seedlings were selected.

\section{Treatments and measured parameters}

Shading treatments at $0 \%$ (full sunlight), 20\% (80\% sunlight), and $60 \%$ (40\% sunlight) were applied for 4 weeks, commenced at 3 weeks after bottom wet culture (WBW) was initiated, and terminated at $7 \mathrm{WBW}$. Black polyethylene net was used in $20 \%$ and $60 \%$ shading treatments. Light intensity underneath both nets was measured using environment meter, set for light intensity (Krisbow KW06-291). Shading percentage was verified by comparing light intensity underneath each net with intensity of direct sunlight nearby with less than 15 second time difference.

Plants were fertilized with $5 \mathrm{~g}$ NPK per pot at 3 and 7 WBW. The plants were re-fertilized at $7 \mathrm{WBW}$ with similar doses due to frequent heavy rains from 3 to 7 WBW. Compound NPK fertilizer used contains $16 \%$ nitrogen, $16 \%$ phosphate $\left(\mathrm{P}_{2} \mathrm{O}_{5}\right)$, and $16 \%$ potassium $\left(\mathrm{K}_{2} \mathrm{O}\right)$ with additional $6 \%$ calcium $(\mathrm{CaO})$ and $0.5 \%$ magnesium (MgO).

During shading treatments, soil moisture and leaf SPAD values were weekly measured. Soil moisture was measured using soil moisture meter (Lutron PMS-714) and leaf SPAD was measured using chlorophyll meter (Konica Minolta SPAD-502Plus). Soil moisture was consistently measured at depth of $5 \mathrm{~cm}$ below soil surface. Measurement of soil moisture at $5 \mathrm{~cm}$ depth was decided since the highest volume of roots in herbaceous vegetables is around $5 \mathrm{~cm}$ depth. For justifying difference between soil moisture near surface at depth of $1 \mathrm{~cm}$ and $5 \mathrm{~cm}$ depth, soil moisture measurement was conducted after 7 consecutive no-rain days.

Effect of shading on soil moisture was evaluated. Furthermore, effect of soil moisture on SPAD value was tested in this study. SPAD value is a direct indicator of leaf greenness and it has been proven to relate directly to chlorophyll content in leaf (Donnelly et al. 2020). In addition, intensity of green color has also been regarded as a quality trait in most leafy vegetables, including leaf celery.

The first harvest was conducted on the day of shading treatment was terminated, i.e. at $7 \mathrm{WBW}$. After that, 4 more harvests were weekly conducted at 10, 11, 12, and 13 WBW. Harvest was executed by picking all individual mature leaves within each pot. Dates of harvest were decided based on availability of marketable-size leaves, except between 7 and 10 WBW which was intentionally done for assessing impact of delaying harvest in leaf celery.

\section{Experiments and leaf area estimation}

During harvesting period, some specific experiments were conducted, including (i) relationship between number of harvested leaves and weights of fresh or dry weight of the leaves; (ii) effects of delaying harvest on marketable yield; (iii) effect of shading intensity on number of suckers produced; (iv) relationship between number of suckers and weight of harvested fresh leaves; and (v) developing leaf area estimation procedures using some geometric measurements as predictors and some regression types in searching for the best-fit model(s).

Leaf area can be estimated using geometric-based models. Seven leaf area (LA) estimation models were tested for their accuracy by comparing predicted value and measured LA and reliability based on value coefficient of determination $\left(\mathrm{R}^{2}\right)$. Five models using single measurement predictor, i.e. length of leaf petiole (LLP), length of leaf midrib (LLM), length of terminal leaflet (LTL), width of terminal leaflet (WTL), and leaf wingspan (LWS). Two models using multiplication of two measurements, i.e. LLM $x$ LWS and LTL $x$ WTL. Leaf midrib covered lengths of rachis, terminal petiolule, and middle vein of terminal leaflet. Leaf wingspan measured based on distance from tip-to-tip of the lowest leaflet pair.

Two types of model used were zero intercepts (through the origin) linear and polynomial regressions. Zero intercept regressions were selected since it was more geometrically sound, i.e. if the selected predictor is zero then leaf area is automatically also zero. To develop and 
validate the models, direct measurement of leaf area was carried out using digital image analyzer developed by Easlon and Bloom (2014).

\section{Data analysis}

Collected data were analyzed using the Analysis of Variance (ANOVA), followed by mean comparison among levels of treatment using the Least Squared Difference at $p$ $\leq 0.05$ (LSD .05$)$. Relationship between two measured parameters was evaluated based on regression and correlation procedures. Specifically, for the leaf area estimation model, zero intercept linear and polynomial regressions were used to predict leaf area, and five single and two double geometric measurements were used as predictors.

\section{RESULTS AND DISCUSSION}

\section{Shading effects on soil moisture and leaf SPAD value}

Higher shading level $(60 \%)$ limited sunlight reaching soil surface; therefore, less energy is available to evaporate liquid water into water vapor at soil surface. Consequently, more water was conserved in soil, i.e. soil moisture was maintained higher under $60 \%$ shading treatment than at $20 \%$ shading and at full sunlight condition or $0 \%$ shading. Soil moisture was higher under low light intensity (Table 1).

Leaf SPAD value in celery under denser shading net $(60 \%)$ was significantly higher than under full sunlight at 3 and $4 \mathrm{WBW}$; however, the effect was not significant at 5, 6, and 7 WBW. Differences at 3 and 4 WBW were most probably associated with NPK fertilizer applications during those two weeks. As mentioned earlier, soil moisture content was higher in $60 \%$ shade treatment. Higher water availability facilitated nitrogen uptake by plant roots at time NPK fertilizer was applied. Higher leaf SPAD value was determined by availability of nitrogen and not by higher soil moisture. This argument was confirmed in Figure 1.
It should be recognized that soil moisture content can be very different between position near soil surface and position deeper under the surface. Figure 2 exhibited these differences between near-surface $(1 \mathrm{~cm})$ and at $5 \mathrm{~cm}$ depth under soil surface. Clearly, soil can be very dry at the evaporating surface; but soil can be very moist at $5 \mathrm{~cm}$ below surface, both under full sunlight or under shaded conditions of $20 \%$ and $60 \%$.

Based on 4 weeks of shading treatment, it was clear that shading did result in better soil moisture in BWC system; but soil moisture did not affect leaf SPAD value. This study indicated that there was no significant effect of shading treatment in leaf celery. Therefore, the treatment was terminated at $7 \mathrm{WBW}$. Application of BWC system was continued until $13 \mathrm{WBW}$ while all plants were fully exposed to full sunlight. Statistical analysis, therefore, was adjusted accordingly.

Sunlight is the primary source of energy for increasing temperature at soil surface. In turn, heat energy at upper layer of moist soil generates evaporation. Sunlight is also the energy source for beneficial photosynthesis but at the same time also generates transpiration in order to maintain leaf temperature within level that safe for plant metabolism, including for protecting enzymes involving in photosynthesis.

\section{Carryover effect of shading treatment}

Carryover effect of previous shading treatment was observed during period of 7 to $13 \mathrm{WBW}$. The first harvest was done at end of shading treatment ( $7 \mathrm{WBW})$. Yield of leaf celery consisted of total fresh weight of marketable leaves. There was inconsistent difference in yield among plants treated with shadings and full sunlight. The second and third harvests showed that yields of plants previously exposed to $60 \%$ shading were significantly lower than those received full sunlight, perhaps the shaded plants needed time for re-adaptation to direct sunlight exposure. Beyond the third harvest, plants previously under 60\% shading were able to recover similar yield levels with plants never been exposed to shading treatment or continuously exposed to full sunlight condition (Table 2).

Table 1. Effect of shading at pre-harvest period on soil moisture and leaf SPAD value in leaf celery

\begin{tabular}{|c|c|c|c|c|c|}
\hline \multirow{2}{*}{ Shading } & \multicolumn{5}{|c|}{ Date of Measurement } \\
\hline & $3 \mathrm{WBW}^{*}$ & $4 \mathrm{WBW}^{*}$ & $5 \mathrm{WBW}$ & $6 \mathrm{WBW}$ & $7 \mathrm{WBW}$ \\
\hline \multicolumn{6}{|l|}{ Soil moisture } \\
\hline $0 \%$ & $9.96 \mathrm{~b}$ & $10.34 \mathrm{c}$ & $13.26 \mathrm{~b}$ & $11.18 \mathrm{~b}$ & $7.98 \mathrm{~b}$ \\
\hline $20 \%$ & $12.29 \mathrm{~b}$ & $15.15 \mathrm{~b}$ & $16.78 \mathrm{ab}$ & $13.41 \mathrm{~b}$ & $7.86 \mathrm{~b}$ \\
\hline $60 \%$ & $16.04 \mathrm{a}$ & $22.14 \mathrm{a}$ & $22.67 \mathrm{a}$ & $17.49 \mathrm{a}$ & $11.97 \mathrm{a}$ \\
\hline LSD.05 & 2.87 & 3.36 & 4.01 & 2.60 & 2.73 \\
\hline \multicolumn{6}{|l|}{$S P A D$} \\
\hline $0 \%$ & $46.21 \mathrm{~b}$ & $45.73 \mathrm{~b}$ & $48.17 \mathrm{a}$ & $46.64 \mathrm{a}$ & $48.34 \mathrm{a}$ \\
\hline $20 \%$ & $47.55 \mathrm{ab}$ & $48.78 \mathrm{ab}$ & $49.09 \mathrm{a}$ & $47.84 \mathrm{a}$ & $50.62 \mathrm{a}$ \\
\hline $60 \%$ & $51.71 \mathrm{a}$ & $51.89 \mathrm{a}$ & $51.15 \mathrm{a}$ & $47.99 \mathrm{a}$ & $47.19 \mathrm{a}$ \\
\hline LSD.05 & 4.55 & 4.80 & $\mathrm{~ns}$ & $\mathrm{~ns}$ & ns \\
\hline
\end{tabular}

Note: ${ }^{*}$ )NPK fertilizers at rate of $5 \mathrm{~g}$ per plant were applied on 3 and $4 \mathrm{WBW}$. Shading treatments were terminated at $7 \mathrm{WBW}$. Means followed by the different letters within columns of each dater of measurement for soil moisture and SPAD are significantly different based on the LSD at $\mathrm{P} \leq 0.05$ 
Table 2. Carryover effect on marketable fresh leaf of celery plants previously exposed to shading treatments

\begin{tabular}{lccccc}
\hline \multirow{2}{*}{ Previous shading } & \multicolumn{5}{c}{ Marketable fresh leaf $(\mathbf{g})$} \\
\cline { 2 - 6 } & $\mathbf{7 ~ W B W *}$ & $\mathbf{1 0} \mathbf{~ W B W}$ & $\mathbf{1 1} \mathbf{W B W}$ & $\mathbf{1 2} \mathbf{W B W}$ & $\mathbf{1 3 ~ W B W}$ \\
\hline $0 \%$ & $40.01 \mathrm{a}$ & $76.85 \mathrm{a}$ & $75.11 \mathrm{a}$ & $66.09 \mathrm{a}$ & $72.20 \mathrm{a}$ \\
$20 \%$ & $40.16 \mathrm{a}$ & $60.51 \mathrm{ab}$ & $82.06 \mathrm{a}$ & $57.82 \mathrm{a}$ & $59.82 \mathrm{~b}$ \\
$60 \%$ & $49.18 \mathrm{a}$ & $44.43 \mathrm{~b}$ & $49.95 \mathrm{~b}$ & $60.37 \mathrm{a}$ & $62.59 \mathrm{ab}$ \\
LSD.05 & $\mathrm{ns}$ & 27.92 & 14.00 & $\mathrm{~ns}$ & 9.95 \\
\hline
\end{tabular}

Note: *) The first harvest was on the same day of shading treatments were terminated. Means followed by the different letters within columns of each date of measurement are significantly different based on the LSD at $\mathrm{P} \leq 0.05$
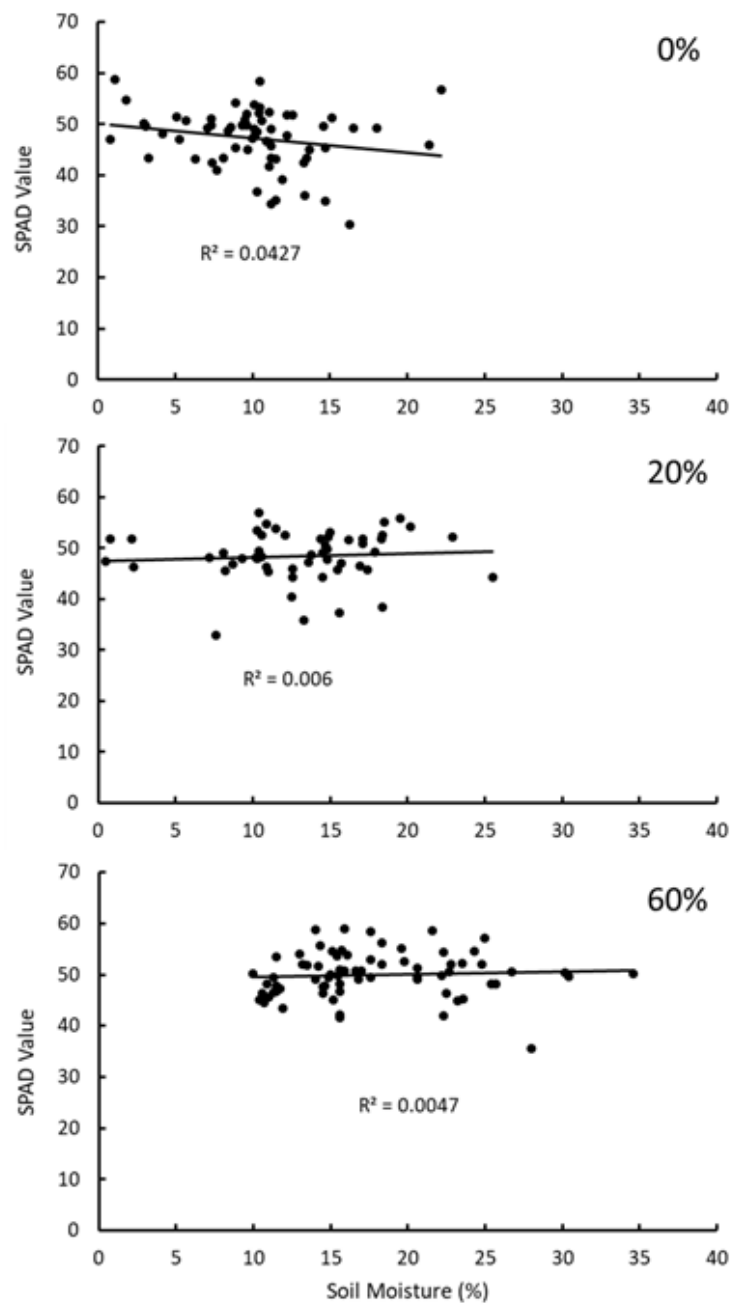

Figure 1. Soil moisture did not affect SPAD values in leaf celery at $0 \%$ (full sunlight), $20 \%$, and $60 \%$ shading

Almost linear relationship between weights of harvested fresh leaves and number of leaves; also, between total dry leaves per plant per harvest and number of leaves (Figure 3 ) indicated that weights of the fresh leaves and total dry leaves were strongly regulated by number of leaves.

Carryover effects reported in many crops had triggered interests in assessing effect of previous shading treatments on yield in leaf celery. Carryover effect can be positive or negative. It was found that negative carryover effect on yield was observed on the second and third harvests, as indicated by significantly lower yield in leaf celery plants previously exposed to $60 \%$ shading. Leaf celery as perennial crop needed extra time for re-adaptation to direct sunlight.

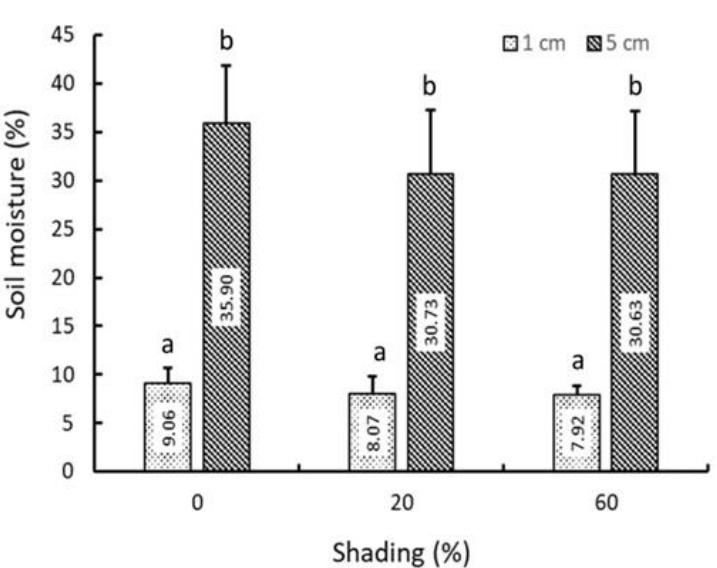

Figure 2. Significant differences in soil moisture measured between 1 $\mathrm{cm}$ and $5 \mathrm{~cm}$ below soil surface regardless of shading levels
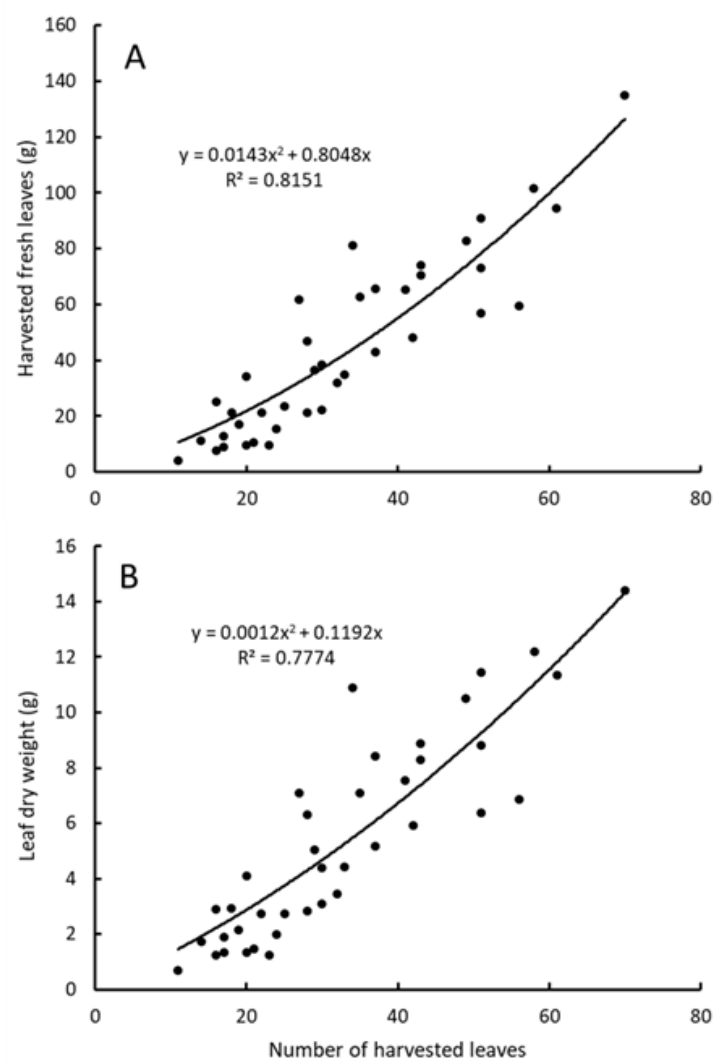

Figure 3. Harvested fresh leaves and leaf dry weight were related to number of harvested leaves 


\section{Delaying harvest, optimum harvest frequency, and sucker contribution to yield}

The second harvest was conducted 3 weeks after the first harvest. Delaying harvest to 3 weeks (instead of weekly) caused significant loss of total marketable yield due to yellowish leaf color, senescence leaf, or suppression on growth of younger leaves due to competition with existed older leaves for nutrient and light; therefore, marketable yield significantly decreased (Figure 4). Potential loss of marketable yields due to delaying harvest to 3 weeks was $31.19 \%, 34.22 \%$, and $52.12 \%$ in plants previously exposed to $0 \%, 20 \%$, and $60 \%$ shading, respectively.

The third, fourth, and fifth harvests were conducted weekly after each previous harvest. Almost $100 \%$ of harvested leaves were marketable at each of these three harvests. At the fourth harvest, the leaf celery plants had produced some suckers. Plants previously exposed to $60 \%$ shading produced significantly less suckers than those exposed to full sunlight and 20\% shading (Figure 5). Number of suckers was moderately $\left(R^{2}=0.5575\right)$ correlated with weight of harvested fresh leaves (Figure 6).

Success in cultivation of perennial celery plants depends on selected frequency of harvest. Delaying harvest to 3 weeks from previous harvest in leaf celery increased total yield and significantly increased percentage of nonmarketable harvested leaves, especially in celery plants previously treated with $60 \%$ shading. In other words, delaying harvest increased quantity of leaf biomass but decreased quality of harvested leaves in leaf celery.

Leaf celery produced many suckers in properly managed in BWC system. Yet, some of suckers were small and not yet able to produce marketable-size leaves. Consequently, correlation between number of suckers and weight of harvested fresh leaves was found to be moderate. There should be an optimum number of suckers for each pot size or population density. Water and nutrients availability determine optimum number of suckers per mother plant.

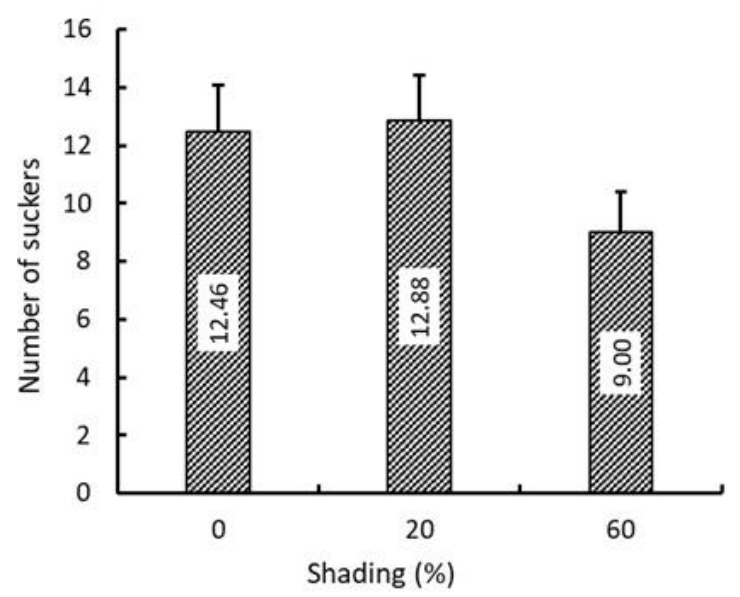

Figure 5. Effects of shading intensity on number of suckers in leaf celery

\section{Leaf area estimation model}

Leaf celery is harvested regularly by picking marketable-size mature leaves. Smaller leaf as found in newly developed suckers is not considered marketable. Leaf is the most economically valuable organ in leaf celery commonly grown in tropical Asia. Leaf celery (Apium graveolens var. secalinum) is different from the stalk celery (Apium graveolens var. dulce), which is mostly cultivated in temperate climate valuable organ is its large petiole or stalk. Since preferred edible organ is leaf blade; therefore, leaf celery plant with large total leaf area and intense green color was preferred by majority of consumer.

Amongst 7 predictors tested, reliable predictors for estimating leaf area in celery were length of leaf midrib (LLM) and leaf wingspan (LWS), either used individually or combined as LLM x LWS (Figure 7). Coefficient determinations were $0.8119,0.8925$, and 0.8724 for LLM, LWS, and LLM x LWS, respectively. Considering high irregularity in the shape of compound leaf in celery, those $\mathrm{R}^{2}>0.85$ were relatively high. Availability of these models makes it possible for non-destructive and accurate estimation of leaf area for each leaf continuously, as base for monitoring leaf expansion rate over a period of time.

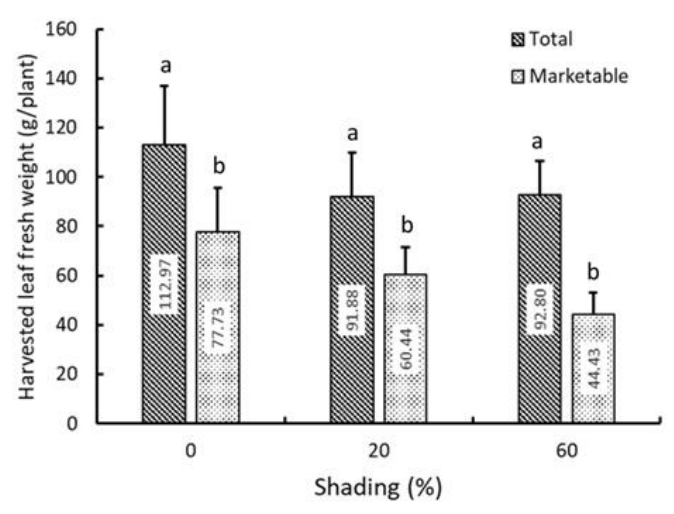

Figure 4. Weights of marketable fresh leaves as affected by delaying harvest in different shading treatments.

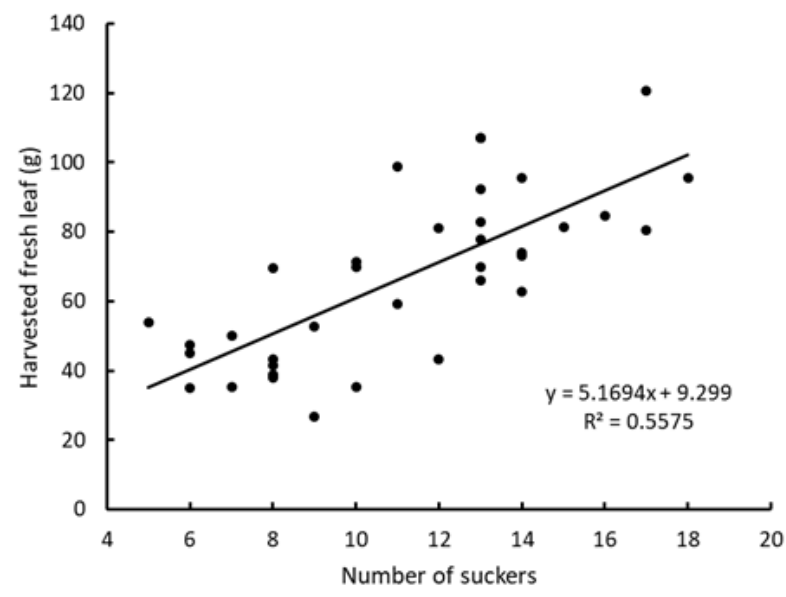

Figure 6. Fresh weight of harvested leaves was affected by number of suckers in leaf celery 

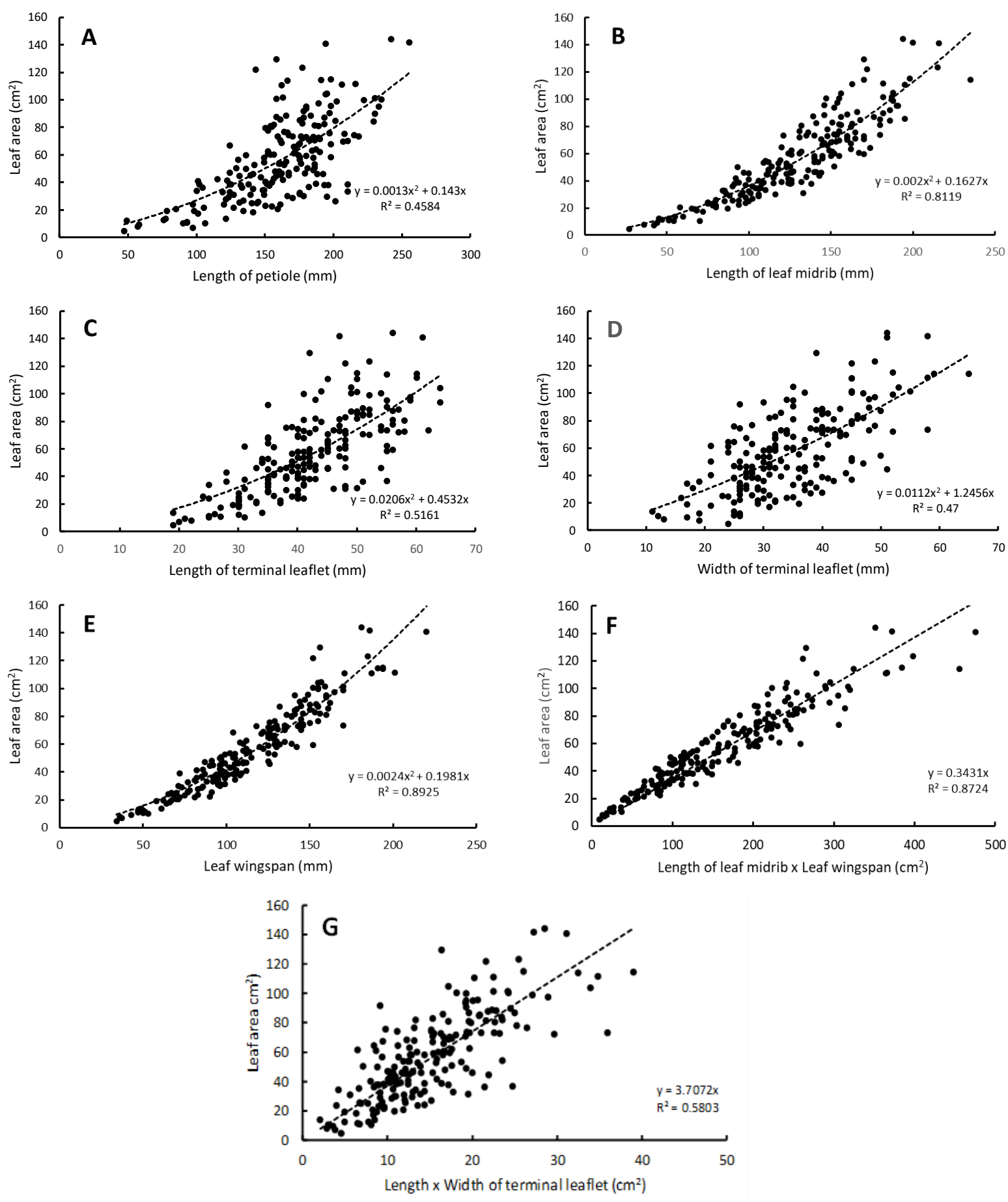

Figure 7. Screening for the most reliable predictor(s) for leaf area estimation in leaf celery (Apium graveolens var. secalinum). Coefficient of determination $\left(\mathrm{R}^{2}\right)>0.80$ is considered as reliable

\section{Discussion}

Shading increased soil moisture but not SPAD value

It has been known for long time that photosynthesis reaches saturation at level far below full intensity of sunlight (Kramer and Decker, 1944), mainly due to limited availability of $\mathrm{CO}_{2}$ (Burnside and Böhning, 1957). Therefore, shading treatment up to $60 \%$ does not potentially affect photosynthetic rate but it decreases evapotranspiration and preserves more soil moisture. Our findings confirmed that soil moisture was significantly higher in $60 \%$ shading compared to full sunlight conditions.

Soil moisture near-surface $(1 \mathrm{~cm}$ depth) can be very dry but slightly below ( $5 \mathrm{~cm}$ depth), it is still steadily moist. Most soil moisture studies over depth of soil horizon focused on depth of $5 \mathrm{~cm}$ to deeper layers and reported that 
the moistest soil layers on yearly average were at 5 to 10 $\mathrm{cm}$ and declined at $15 \mathrm{~cm}$ and deeper (Penna et al. 2013). Soil moisture at depth of $1 \mathrm{~cm}$ below surface has rarely been measured, despite the first $5-\mathrm{cm}$ soil layer is where the most probable moisture and temperature dynamics are happening. Presence of biological soil crust on soil surface increased soil moisture at $5 \mathrm{~cm}$ depth but decreased soil moisture at depth of $15-50 \mathrm{~cm}$ (Xiao et al. 2016).

In contrast to rain-dependent and open irrigated systems, water in BWC system was originated from bottom of substrate and moved upward due to capillarity (Novak and Hlavacikova 2019) and also the substrate prevented water from percolating to deeper layer (Hubner et al. 2017) due to hydrophilic nature of the substrate; therefore, measurement of soil moisture at $5 \mathrm{~cm}$ represented the whole rhizosphere, except for near-surface layer which directly affected by heat energy absorbed from sunlight. However, water-saturated rhizosphere would not happen since free water molecules within soil pores are pulled down by gravitational force.

Leaf SPAD value has been used as an indirect estimation of leaf chlorophyll and nitrogen contents; however, equipment so-called as chlorophyll meter measures intensity of green color of leaf. Therefore, leaf SPAD value is useful equipment for rating leaf quality in leafy green vegetables, including leaf celery. Consumers prefer intense green color of celery leaf.

There was inconsistent effect of shading on leaf SPAD value. Shading increased leaf SPAD value or chlorophyll concentration in rice ( $\mathrm{Li}$ et al. 2018) and tea (Sano et al. 2018); on the other hand, Jeranyama et al. (2017) reported that shading significantly lowered total chlorophyll concentration in cranberry. In this study, leaf SPAD value was affected neither by soil moisture nor by shading treatments. Leaf quality did not differ significantly between shaded and unshaded treatments. It was also not affected by different soil moisture content in leaf celery cultivated using BWC system.

\section{Short duration of carryover effect of shading treatment}

Since there were no significant effects of shading and soil moisture on quality of leaf celery; continuation of research was shifted to find optimum harvesting frequency, its impact to marketable yield, and evaluate carryover effect of previous shading treatments. Leaf celery is a perennial crop (Sallam 2019), multiple and frequent harvests can be continuously done given that the crop was supplied with adequate water and essential nutrients.

Carryover effects in plants due to previous exposure to abiotic stress or specific treatment could befall at various responses. For instance, Lawrence et al. (2017) reported that the carryover effect of previous defoliation treatment in autumn was rewarded with increased yield and better quality of ryegrass in spring of the following year. Ryegrass is a pasture grass for livestock. In other cases, Simpson et al. (2019) reported that grass growth and development were influenced by prior fire exposure and the effect was independent of environmental conditions. Moreover, Rendina-González et al. (2018) was convinced that transgenerational effects were common in clonal herb white clover (Trifolium repens).

Kromdijk et al. (2016) explained that plants protect themselves by dissipating excess light energy in form of heat energy when exposed to full sunlight; consequently, it causes less efficient photosynthetic process. It took time for the plants to readjust their system. Fan et al. (2018) reported that soybean as an annual crop could not fully recover from shading after being re-exposed to full sunlight at the early reproductive stage. Carryover effect in leaf celery was only last for 4 weeks. Beyond the 4-week period, plants previously exposed to $60 \%$ shading had recovered to similar yield level of plants under full sunlight conditions.

Economically, valuable part of leaf celery is its musky leaf blade, not its petiole or crunchy stalk as in stalk celery or its fleshy root as in celeriac. Individual leaf, including its long but slender petiole, is manually harvested and bundled for marketing. Therefore, postharvest handling is desirable to have leaves with uniform size (Shewfelt et al. 2014). Celery leaves were very uniform in this study as indicated by strong $\left(\mathrm{R}^{2}=0.815\right)$ and almost linear correlation between the number of leaves and the weights of harvested fresh leaves. Cultivation of leaf celery as a perennial crop is more environmentally friendly than treated celery as an annual crop, since the later can potentially cause soil loss at rate ranged from 1.4 to $8.5 \mathrm{Mg} \mathrm{ha}^{-1}$ per harvest (Parlak et al. 2018).

Avoiding delayed harvest and optimizing harvest frequency

Bellaloui et al. (2017) found that delayed harvest in soybean could be beneficial but at the same time could also be disadvantageous. Delayed harvest increased boron and lignin in seed coat. Boron and lignin involved in maintaining seed coat integrity and protecting seed coat against physical damage. However, delayed harvest decreased both organic and inorganic seed components in soybeans (Jaureguy et al. 2013).

Rice is an example of sensitive plant to delayed harvest. Highest head rice yield was achieved if rice was harvested at 25 days after flowering. Delaying harvest to 35 or 45 days after flowering decreased yield significantly regardless of harvesting methods, i.e., using combine harvester or by hand (Bunna et al. 2019). Even delayed only for 5 days, rice yield had been significantly reduced (Xangsayasane et al. 2019).

Negligible non-marketable harvested leaves with steady quantity of yield was achieved in leaf celery if frequency of harvest was executed weekly, as shown on the third, fourth, and fifth harvests at 11,12 , and $13 \mathrm{WBW}$, respectively. Another perennial horticultural crop that requires frequent harvests is chili pepper. While leaf celery is harvested in line with time at which the leaf had reached marketable size; chili pepper is timely harvested following fruit maturity throughout harvesting period. Mature chili fruits should be harvested every 2-3 days starting from 12 weeks after transplanting. Peak yield was reached at 13 weeks after transplanting; thereafter, yield gradually declined (Siaga et al. 2018). 


\section{Justifying zero intercept regression models}

Developing estimation model for leaf area of a single regular-shaped leaf is obviously much simpler than an oddpinnately compound leaf with multiple leaflets, such as in celery leaf. Therefore, most leaf area estimation models were developed in plants with single leaf. Some models were purely mathematics (Serdar and Demirsoy 2006), not considering geometry of leaf which is constructed by two dimensions of length and width (the third leaf dimension of thickness is usually negligible), using only single predictor either leaf length (L) or leaf width (W), and more focused on coefficient of determination $\left(R^{2}\right)$ value. $R^{2}>0.95$ was commonly achieved using simple linear, polynomial, or power regression model with single predictor for single leaf with regular shape.

More recent leaf area estimation models were considered and aware of the two-dimensional nature of leaf; however, most still used a simple regression model (Walia and Kumar 2017; Fascella et al. 2018), without zeroing the intercept. Most simple regression and other models have serious bias in estimating leaf area of smaller size leaves, culminated at point if $\mathrm{L}=0$ and/or $\mathrm{W}=0$. It absolutely does not make sense if $\mathrm{LA} \neq 0$ if $\mathrm{L}=0$ and $\mathrm{W}=$ 0 .

Only few had used zero intercept linear or polynomial regression in estimating leaf area (Lakitan et al. 2017; Meihana et al. 2017; Widuri et al. 2017). Despite, leaf area estimation model had been developed as early as 1930's (Hopkins, 1939) or earlier; zero intercept regression or regression through the origin had only been used since 1980's (Lakitan, 1989) or perhaps a bit earlier. In this study, zero intercepts linear and polynomial regression were used. In order to make sure that $\mathrm{LA}=0$ if $\mathrm{L}=0$ and $\mathrm{W}=0$.

As an overall conclusion, shading treatments at $60 \%$ significantly increased soil moisture content. However, both direct effect of shading and soil moisture did not affect leaf SPAD value. In any case, leaf SPAD values were already around 50. Soil moistures within rhizosphere in each pot across treatments were more than adequate for supporting growth of leaf celery although they were significantly dry at surface to $1 \mathrm{~cm}$ depth. Leaf celery exhibited early carryover negative effect of previous $60 \%$ shading exposure but recovered to comparable yield with those previously exposed to full sunlight and $20 \%$ shading after 4 weeks of shading treatment was terminated. Delaying harvest to 3 weeks increased total yield but more than half of harvested leaves were non-marketable in plants exposed to $60 \%$ shading. Optimal harvest frequency was weekly of a week after every previous harvest. Number of suckers moderately correlated with weight of harvested leaves, since most young suckers were not yet able to produce marketable-size leaf. Geometrically based and accurate leaf area estimation models were achieved using LLM x LWS as predictor and zero intercept linear or polynomial regression. The recommended model is LA = 0.3431 (LLM x LWS).

\section{ACKNOWLEDGEMENTS}

We deeply appreciate anonymous reviewers and editors of this journal for their comments and suggestions. Program Penelitian Unggulan Profesi Universitas Sriwijaya funded this research, Grant No. 0687/UN9/SK.BUK.KP/2020.

\section{REFERENCES}

Abdel-Ghany AM, Al-Helal IM. 2020. Toward sustainable agriculture: net-houses instead of greenhouses for saving energy and water in arid regions. In: Stagner J, Ting DK (eds.). Sustaining Resources for Tomorrow. Springer, Cham.

Bellaloui N, Smith JR, Mengistu A. 2017. Seed nutrition and quality, seed coat boron and lignin are influenced by delayed harvest in exoticallyderived soybean breeding lines under high heat. Front Plant Sci 8: 1563. DOI: $10.3389 /$ fpls.2017.01563.

Bunna S, Sereyvuth H, Somaly Y et al. 2019. Head rice yield of crops harvested by combine and hand at different ripening times in Cambodia. Exp Agric 55: 132-142.

Burnside CA, Böhning RH. 1957. The effect of prolonged shading on the light saturation curves of apparent photosynthesis in sun plants. Plant Physiol 32: 61-63.

Donnelly A, Yu R, Rehberg C, Meyer G, Young EB. 2020. Leaf chlorophyll estimates of temperate deciduous shrubs during autumn senescence using a SPAD-502 meter and calibration with extracted chlorophyll. Ann For Sci 77: 1-12.

Easlon HM, Bloom AJ. 2014. Easy leaf area: automated digital image analysis for rapid and accurate measurement of leaf area. Appl Plant Sci 2: 1400033. DOI:10.3732/apps.1400033.

Fan Y, Chen J, Cheng Y, et al. 2018. Effect of shading and light recovery on the growth, leaf structure, and photosynthetic performance of soybean in a maize-soybean relay-strip intercropping system. PloS One 13. DOI: 10.1371/journal.pone.0198159.

Fascella G, Rouphael Y, Cirillo C, Mammano MM, Pannico A, de Pascale S. 2018. Allometric model for leaf area estimation in bougainvillea genotypes. Acta Hort 1215: 449-452.

Herden T, Bönisch M, Friesen N. 2020. Genetic diversity of Helosciadium repens (Jacq.) WDJ Koch (Apiaceae) in Germany; a crop wild relative of celery. Ecol Evol 10: 875-890.

Hopkins JW. 1939. Estimation of leaf area in wheat from linear dimensions. Canadian J Res 17: 300-304.

Hubner R, Gunther T, Heller K, Noell U, Kleber A. 2017. Impacts of a capillary barrier on infiltration and subsurface stormflow in layered slope deposits monitored with 3-D ERT and hydrometric measurements. Hydro Earth Syst Sci 21: 5181-5199.

Jaureguy LM, Ledesma-Rodriguez F, Zhang L, et al. 2013. Planting date and delayed harvest effects on soybean seed composition. Crop Sci 53: 2162-2175.

Jeranyama P, Sicuranza J, Hou HJ, de Moranville C. 2017. Shade effects on chlorophyll content, gas exchange and nutrient content of cranberry vines exhibiting yellow vine symptoms. J Appl Hort 19: 37.

Kaur J, Rawat A, Renu SK, Narain S. 2016. Taxonomy, phytochemistry, traditional uses and cultivation of Ipomoea aquatica Forsk. Imperial J Interdisipl Res 2: 408-412.

Kromdijk J, Głowacka K, Leonelli L, Gabilly ST, Iwai M, Niyogi KK, Long SP. 2016. Improving photosynthesis and crop productivity by accelerating recovery from photoprotection. Science 354: 857-861.

Kramer PJ, Decker JP. 1944. Relation between light intensity and rate of photosynthesis of loblolly pine and certain hardwoods. Plant Physiol 19: 350-358.

Lakitan B. 1989. Empirical model for estimating leaf area in bean (Phaseolus vulgaris L.). Ann Report Bean Improv Coop 32: 19-21.

Lakitan B, Juliani F, Sodikin E. 2019. Ability of Limnocharis flava to escape from episodic submersion by rapid elongation of its leaf petiole. Bulgarian J Agric Sci 25: 314-319.

Lakitan B, Iwanaga H, Kartika K, Kriswantoro H, Sakagami JI. 2018a. Adaptability to varying water levels and responsiveness to NPK fertilizer in yellow velvetleaf plant (Limnocharis flava). Aust J Crop Sci 12: 1757-1764. 
Lakitan B, Kadir S, Wijaya A, Susilawati S. 2018b, Tolerance of common bean (Phaseolus vulgaris L.) to different durations of simulated shallow water table condition. Aust J Crop Sci 12: 661-668.

Lakitan B, Widuri LI, Meihana M. 2017. Simplifying procedure for a nondestructive, inexpensive, yet accurate trifoliate leaf area estimation in snap bean (Phaseolus vulgaris). J. Appl Hort 19: 15-21.

Lawrence DC, O'Donovan M, Boland TM, Kennedy E. 2017. Effects of autumn and spring defoliation management on the dry-matter yield and herbage quality of perennial ryegrass swards throughout the year. Grass Forage Sci 72: 38-49.

Li W, Zeng F, Wang X, Wang J, Wang G. 2018. Effect of shading on gas exchange and chlorophyll fluorescence of rice leaves in suckering stage. Southwest China J Agric Sci 31: 289-295.

Meihana M, Lakitan B, Susilawati, Harun MU, Widuri LI, Kartika K, Siaga E, Kriswantoro H. 2017. Steady shallow water table did not decrease leaf expansion rate, specific leaf weight, and specific leaf water content in tomato plants. Aust J Crop Sci 11: 1635-1641.

Novak V, Hlavacikova H. 2019. Soil-water movement in water-saturated capillary porous media. In: Novak V, Hlavacikova H (eds.). Applied Soil Hydrology. Springer, Cham.

Parlak M, Çiçek G, Blanco-Canqui H. 2018. Celery harvesting causes losses of soil: a case study in Turkey. Soil Tillage Res 180: 204-209.

Penna D, Brocca L, Borga M, Dalla-Fontana G. 2013. Soil moisture temporal stability at different depths on two alpine hillslopes during wet and dry periods. J Hydrology 477: 55-71.

Rendina-González AP, Preite V, Verhoeven KJ, Latzel V. 2018 Transgenerational effects and epigenetic memory in the clonal plan Trifolium repens. Front Plant Sci 9: 1677. DOI: 10.3389/fpls.2018.01677

Sallam S. 2019. Phytochemical studies on celery (Apium graveolens L.) plant using chemical fertilization, biofertilizer and thidiazuron treatments. Al-Azhar J Pharma Sci 59: 54-65.

Sano T, Horie H, Matsunaga A, Hirono Y. 2018. Effect of shading intensity on morphological and color traits and on chemical components of new tea (Camellia sinensis L.) shoots under direct covering cultivation. J Sci Food Agric 98: 5666-5676.
Serdar Ü, Demirsoy H. 2006. Non-destructive leaf area estimation in chestnut. Scientia Hort 108: 227-230.

Shewfelt RL, Prussia SE, Sparks SA. 2014. Challenges in handling fresh fruits and vegetables. In: Florkowski WJ, Shewfelt RL, Brueckner B, Prussia SE (eds.). Postharvest Handling. Academic Press, Waltham, MA.

Siaga E, Lakitan B, Hasbi, Bernas SM, Wijaya A, Lisda R, Ramadhani F, Widuri LI, Kartika K, Meihana M. 2018. Floating culture system of chili pepper (Capsicum annum L.) during high flooding period at riparian wetland in Indonesia. Aust J Crop Sci 12: 808-816.

Siaga E, Sakagami JI, Lakitan B, Yabuta S, Hasbi, Bernas SM, Kartika K, Widuri LI. 2019. Morpho-physiological responses of chili peppers (Capsicum annuиm L.) exposed to short-term water-saturated rhizosphere. Aust J Crop Sci 13: 1865-1872.

Simpson KJ, Olofsson JK, Ripley BS, Osborne CP. 2019. Frequent fires prime plant developmental responses to burning. Proc R Soc Biol Sci 286. DOI:10.1098/rspb.2019.1315

Susilawati, Lakitan B. 2019. Cultivation of common bean (Phaseolus vulgaris L.) subjected to shallow water table at riparian wetland in South Sumatra, Indonesia. Aust J Crop Sci 13: 98-104.

Xangsayasane P, Vongxayya K, Phongchanmisai S, Mitchell J, Fukai S. 2019. Rice milling quality as affected by drying method and harvesting time during ripening in wet and dry seasons. Plant Prod Sci 22: 98-106.

Xiao B, Hu K, Ren T, Li B. 2016. Moss-dominated biological soil crusts significantly influence soil moisture and temperature regimes in semiarid ecosystems. Geoderma 263: 35-46.

Walia S, Kumar R. 2017. Development of the non-destructive leaf area estimation model for valeriana (Valeriana jatamansi Jones). Comm Soil Sci Plant Anal 48: 83-91.

Widuri LI, Lakitan B, Hasmeda M, Sodikin E, Wijaya A, Meihana M, Kartika K, Siaga E. 2017. Relative leaf expansion rate and other leafrelated indicators for detection of drought stress in chili pepper (Capsicum annuиm L.). Aust J Crop Sci 11: 1617-1625. 